Adrian Gosk

\title{
THE DEVELOPMENT AND PROSPECTS OF AN INTERNAL AUDIT IN PUBLIC FINANCE SECTOR UNITS IN POLAND
}

\section{Initial comments}

The introduction of an internal audit was connected with adapting Polish legal system to the European standards as a part of our accession to the European Union. During the time of a socialist state, but also after the crucial events of 1989, Polish administration consisted of similar internal control units, however, during the negotiations the stance of Polish negotiators was not accepted. The main reason for this were basic differences between these two institutions. Namely, internal control is a means of management which aims at revealing inadvertence and incorrectness, while an internal audit is supposed to facilitate (bring in the so called positive value) at the same time bearing quite an independent position in an organization. ${ }^{1}$ Although it has been present in a Polish legal system for a few years, an internal audit is still quite a new institution and till now there have been a lot of doubts concerning its role and character, especially in local government units.

\section{Internal audit from 2002 to 2005}

This institution enriched Polish legal system by adding on the $1^{\text {st }}$ January 2002 chapter no. 5 entitled: "Financial control and internal audit in public finance sector units" (art. $35 \mathrm{a}-35 \mathrm{t}$ ufp) to the act dated $26^{\text {th }}$ November 1998 concerning public finance. ${ }^{2}$ The legislator's intention was mutual regulation of similar, in their opinion, institutions namely: financial control and an internal audit. ${ }^{3}$ In accordance with the article 35a ufp financial control in public finance sector units was supposed to relate to the process connected with accumulating and administering public means as

K. Czerwiński, Audyt wewnętrzny, Warsaw 2004, p.16

Act dated 26th November 1998 concerning public finance (Law Gazette No. 15 item 148 with amendments, hereinafter referred to as: "ufp")

3 R. Krzemień, K. Winiarska, Audyt wewnętrzny w pytaniach i odpowiedziach. Komentarze, Warsaw 2004, p.10 
well as property management. Financial control was supposed to include: obeying control procedures and initially evaluate the purposefulness of taking out financial obligations, bearing expenses, examination and comparison of actual and required state, taking and accumulating public means, giving competitive tendering and returning public means as well as managing financial economy. Whereas an internal audit in art. $35 \mathrm{c}$ of the same act was described as the whole of the actions by which the unit's manager gets objective and independent evaluation of the functioning of the unit as far as financial economy is concerned (by checking accounting evidence and accounting books' records, evaluating public means accumulation and distribution system as well as property management and effectiveness as well as economical financial management evaluation). The statement: "in particular" showed an open catalog of auditing activity although the mentioned items showed the main direction - verification of financial processes and their reflection in accounting units. ${ }^{4}$ The regulations, at this time, did not mention anything about the advisory function.

Limiting the scope of an internal audit activity to the financial sphere only served a protective function. The reason for such regulations' construction was, in my point of view, incorrect interpretation by the Polish party of the objectives of internal audit existence, which was in turn connected with a cursory survey of European regulations. ${ }^{5}$ What was also worth mentioning, were the objections of the units' managers who were afraid of a radical increase of transparency concerning the processes which take place in the managed units. Another interesting thing is the fact that the problem still remains, which is reflected in the number of negative opinions despite a crucial change in regulations enabling auditors to verify the whole of the organization's activity. ${ }^{6}$

In the scope of a subjective register of the institutions obliged to introduce an internal audit, the legislator decided upon quite an unfortunate solution, which meant enumerating these institutions in the first excerpt of the art. $35 \mathrm{~d}$ ufp as well as adding, in the following excerpt, the information which stated that the register also includes other units provided they accumulate considerable public means or bear considerable public expenses. From the point of view of the care for succinctness and clarity of the text, which is typical of the legislation process, such a solution appears to be quite weak. Some practitioners explain the shape of the regulation by the wish to emphasize the importance of some chosen public institutions. The long list of the enumerated institutions includes: the Sejm, Senate and President of the Republic of Poland, Chancelleries, the Supreme Court, the High Administrative

4 E. Chojna-Duch, Kontrola czy audyt Najwyższej Izby Kontroli?, "Kontrola Państwowa” issue XLVII February 2002 - special edition

5 D.McNamee, Oszacowanie ryzyka w audycie wewnetrznym i zarządzaniu. Warsaw, p.23

6 A good example of this is a critical opinion, expressed by judicial circles, of ufp regulations concerning internal audit in judicature - A. Łukaszewicz, Dyrektor powinien liczyć się z prezesem, "Rzeczpospolita" No. 792008 , p.C3 "Prawo co dnia" supplement 
Court, Constitutional Tribunal, National Judiciary Council, common judicature, the Supreme Chamber of Control, ministries, Prime Minister's Chancellery, central and provincial offices as well as customhouses and Inland Revenues. Changes in this scope, during the time the act was in force, were not considerably important:

a) first of all, from $31^{\text {st }}$ December 2002 the directory was enlarged by common organizational units of the public prosecution service as well as the prison service ones (one cannot resist the impression that in the original text they were simply omitted);

b) secondly, since $1^{\text {st }}$ April 2003, in relation to the health insurance system reform, healthcare funds were replaced by one fund, which is: National Health Fund ("NFZ"), which theoretically narrowed down the obligation to conduct internal audit from a few to one unit. In reality the organizational structure of NFZ included its head office as well as 16 local departments, which were housed in formal regional healthcare funds (internal audit organizational units still remained both in the head office and local departments).

As far as the remaining units are concerned (art. 35d act. 2 ufp), the legislator authorized the Minister of Finance to specify the threshold of income and public means expenditure whose exceeding resulted in the necessity to introduce an internal audit as well as the deadline of its introduction. The Minister of Finance by means of the regulation which was made 12 months after the act was introduced, established the sum to be 35 million zloty and obliged to introduce an internal audit before the end of the first quarter of the year which followed the year in which the sum was exceeded. ${ }^{7}$ It was a wish to successively introduce a new institution into Polish public finance units that can explain a doubtful structure of art. 35d ufp. The units holding a strong position and having considerable potential were forced to introduce an internal audit first while its introduction in the remaining units could be blocked by the lack of executive regulations for a few months.

Since 2002 the internal audit system has been based on internal auditors as well as the Minister of Finance acting as a coordinating organ. Because of the fact that public administration urgently needed a large group of people with specific qualifications whereas the then university offer did not enable to complete suitable education quickly, the legal requirements were not too demanding. Firstly, one should be of a Polish nationality, have higher education, legal capacity and be fully able to use public law. A candidate could not have a criminal record for a crime they committed deliberately. Such a person could take an examination in front of an examination board appointed by the Minister of Finance, and passing this exam

$7 \quad$ Minister of Finance regulation dated December 20th 2008 concerning the threshold of income and public means expenditure whose exceeding results in the necessity to introduce an internal audit in public finance sector units (Law Gazette No. 234, item. 1970) 
with a positive result was a second necessary requirement needed to receive the qualifications. A positive attitude towards the candidates was shown by the fact that sample questions and written exam tasks were announced publicly on a Ministry of Finance's web page. A coordinating process included: analytical, informational and training activity as well as cooperation with international institutions. Despite having the right to evaluate the job from the perspective of rules and standards implementation, the verification of the coordinating unit was, at that time, mainly based on supporting auditors.

Employing auditors in each of the planned public units proved to be very difficult as well as not very economical. In accordance with the original version of ufp, the exceptions only concerned national budget units operating outside Poland (an audit was supposed to be conducted by an auditor employed in a superior or supervisory unit). Since $1^{\text {st }}$ May 2002 a new regulation has been introduced (art. 35e act.2a ufp) according to which customs and revenue offices were supposed to be checked by auditors from customs or revenue offices. Since $31^{\text {st }}$ December 2002 the regulations concerning the judiciary that is: courts, public prosecution services and prison management, were analogically adapted (art. $35 \mathrm{e}$ act.2b - 2e ufp). And a question arises here whether this type of a legal structure guarantees job's independence? If an internal auditor is a worker employed by the superior (supervisory) unit, they are automatically subordinated to the manager of such a unit, who is in turn more interested in realizing their supervisory function than receiving objective and independent evaluation of the subordinated unit.

A detailed method of conducting internal audit on the basis of legal authorization was specified by the Ministry of Finance regulation dated $5^{\text {th }}$ July $2002 .^{8}$ This regulation, among other things, specifies the methods of preparing the plan of the audit as well as the rights and responsibilities of the auditor and the way they document their activity. A person responsible for setting standards compared the characteristics of their job to the job done by a chartered auditor, additionally evaluating the purposefulness, economy and punctuality of tasks' management.

\section{Internal audit since 2006}

A successive act concerning public finance dated July $30^{\text {th }} 2005,{ }^{9}$ which was effective from $1^{\text {st }}$ January 2006, brought about important legal changes. Chapter no. 5 was devoted to the issues concerning internal audit - "Internal audit and financial control and internal audit coordination in public finance sector units" (art. 48-

\footnotetext{
8 Minister of Finance regulation dated 5th July 2002 concerning detailed ways and methods of conducting an internal audit (Law Gazette No. 111 item. 973)

9 An act concerning public finance dated July 30th 2005 (Law Gazette No. 249, item. 2104 with amendments, hereinafter referred to as "nufp")
} 
67 nufp). The legislator drew a distinctive division between financial control and internal audit, at the same time radically changing the characteristics of the latter institution. Financial control, until now so closely connected with an interior auditor, was attributed to the unit's manager who was obliged to introduce suitable changes to the company's rules or regulations or to give personal permission in order to assign the responsibility in this respect to any company's worker. However, the auditors were ascribed to realize the function which enabled independent research into management and control systems of the unit. A second of the ascribed functions included advisory activity which aimed at improving the unit's function. This change does not mean getting rid of a financial or budget report evaluation, but it indicates a crucial change in the legislator's approach. ${ }^{10}$ Purely financial verification model was renounced giving way to the broad auditing of the activity.

The subjective register of the units enumerated in the previous act was enlarged with: provincial administrative courts, Office of the Committee for European Integration, customs and revenue offices and regional clearing houses. In case of the first two mentioned units as well as the Government Center for Strategic Studies, which was crossed out from the list in connection with its liquidation dated $1^{\text {st }}$ April 2006 , the changes simply resulted from the political system reforms in these regions. What casts doubts is adding the rest of the institutions to the register, especially as a part of them met the requirements on the basis of the following excerpt of the same act's article (art. 49 act.2 nufp). Threshold amounts obliging a company to introduce an internal audit increased from 35 to 40 million zloty, ${ }^{11}$ which led to considerable confusion. Although the increase of the amount was relatively small, there was substantial confusion in some units concerning the existence of legal obligations. The regulation included unfortunate point no.5 imposing an obligation to conduct an internal audit to, at least, $31^{\text {st }}$ March 2007 in the units which exceeded the amounts described in the previous regulation and which did not meet the requirements on the basis of the new regulation. What seems to be a reasonable solution is to oblige the units which started introducing an internal audit to continue the process without the possibility of having a choice.

The system of an internal audit characterized by the nufp rules was similar to the rules which operated before. Again, the legislator enumerated the list of institutions in which the audit was conducted by the auditors who were not employed in the units (the register included the list of institutions from the previous regulation with two exceptions). As a result of an earlier model's failure (too large scope of actions) the idea to conduct internal audit in customs and revenue offices by the auditors employed in customs and revenue offices respectively, was resigned from.

10 B. R. Kuc, Audyt wewnętrzny-teoria i praktyka, Warsaw 2002

11 The Minister of Finance regulation dated 24th July 2006 concerning the amounts whose exceeding results in introducing internal audit in public finance sector units (Law Gazette No. 112, item.763) 
A second issue was a rule which assumed conducting internal audit in state tertiarylevel schools that did not exceed the amount of expenditure and outcomings which oblige to introduce an internal audit. Such an audit should be conducted by the interior auditor employed in a ministry who supervises the school or in any other tertiary-level school, supervised by the minister of higher education on the basis of the university presidents' agreement. Then there has been a break in a subjective register in art. 49 of nufp. Finally, art. 51 point 12 gives the internal auditor employed in a superior or supervising unit the possibility to conduct an audit, although the institution was originally created, first of all, to serve a public unit's manager. Supposing that the regulation is used reasonably, this solution may elasticize or improve the use of auditing resources. However, if a superior or supervisory unit's manager has an ill will (resulting from political pressure), the institution may get considerably distorted.

The introduction of the possibility to employ persons without auditing qualifications in the audit units deserves apparent recognition. This enabled to construct them on the basis of a supervising auditor model and other workers realizing freelance and supporting functions. This rule may be of great help in verifying a candidate for auditor's predispositions.

Considerable changes also concerned acquiring professional qualifications. The following requirements were maintained: higher education, legal capacity, being fully able to use public law and not having a criminal record for a crime committed deliberately. The change concerning the possibility to hold an auditor's position by the citizens of other countries belonging to the European Union, Swiss Confederation and the countries of the European Economic Area agreement (Iceland, Lichtenstein, Norway) resulted from the European regulations concerning labour law. Besides, the possibility to employ such a person was planned only if detailed regulations did not require to have Polish nationality. Taking into account Polish salaries with relation to the European average of earnings, it can not be expected that this regulation will considerably influence a labour market. The biggest change concerned giving up the obligation to take ministerial examinations and introducing a need to hold other documents such as: international certificates, the certificates which confirm passing inspector's exams in the Supreme Chamber of Control ("NIK") and enable to hold a position of a tax control inspector or a chartered auditor. The legislator's intention was raising the level of factual knowledge. What causes doubts is the multitude of possibilities to obtain professional qualifications. First of all, the list of international certificates included eight positions characterized by different professional levels. The list includes the following certificates: CIA, CGAP, CISA, ACCA, CFE, CCSA, CFSA and CFA. On the one hand, a similar experience gained at the post of a chartered auditor, NIK inspector or a tax control inspector enables to handle an auditor's function. On the other hand, however, none of these positions professionally 
prepares to fulfill an auditor's function. It can be assumed that the actions taken by an interior auditor, including the most important one which is a risk evaluation, will be determined by the auditor's earlier professional career. In my point of view, the regulation mentioned in art. 58 nufp is only a temporary solution, and acquiring auditor's qualifications in the future will have to become similar to obtaining a legal profession (unified rules for achieving professional titles, professional selfgovernment supervision and so on).

Another increase concerned the competences of the organ coordinating an internal audit process. The issue is that there is a possibility for the Minister of Finance to order auditing tasks since $29^{\text {th }}$ December 2006. It is quite a questionable solution - that is why an external subject, in relation to an often equivalent unit, is equipped with this instrument (including ordering the audits which do not concern spending public means directly and which are called task completing audits).

A detailed way to conduct an internal audit on the basis of the legal regulation included in nufp was specified by the Minister of Finance regulation dated July $24^{\text {th }}$ 2006. ${ }^{12}$ Apart from the issues parallel to those regulated in the previous regulation, the regulations concerning the change of internal audit's characteristics appeared. They especially included the ones which specified advisory activities.

\section{An internal audit according to the 2005 projects}

Together with the change of the political pattern in Poland since 2005 the opinions concerning a quick and radical change of nufp have appeared. A next regulation concerning public finance actually expected introducing considerable changes, although they were to concern an internal audit in only a minor part. This can mean that despite different visions of public finance management, the issues concerning an internal audit do not belong to the contentious ones. What is worth paying attention to is the fact that there has been a change in the Minister's of Finance position as a coordinating unit and the introduction to nufp the regulations concerning the possibility to order audits during the 2005 government coalition. Other issues worth mentioning here include: a return to the model based on conducting an internal audit in customs offices by an auditor employed in customs chamber (it has been accepted that as opposed to many revenue offices on the Internal Revenue Service domain, such a solution in customs offices would be optimal) as well as a duty to inform the Minister of Finance about the cases of conducting an internal audit in the units subordinated or supervised by the auditors employed in superior or supervising units. 
This planned act was enriched with a subsequent regulation's project concerning detailed ways and methods of conducting internal audits which, among other things, regulated the issues concerning an ordered internal audit. It has been stated that such an audit will be conducted in accordance with organizational and factual principles prepared in the Ministry of Finance. The Ministry of Finance being a place where a report written after an audit was conducted and is immediately handed over. And the cooperation with the authorized ministry workers should be based on enabling them to freely enter the institutions and premises which undergo audit processes and obtain requested documentation in an electronic version. Not taking into account the recklessness of the last regulation and considering the real situation in the Polish administration (electronic versions are prepared in case of only few documents), it is worth pointing out that if these regulations become applicable, they would bring the competences of the Ministry of Finance authorized workers closer to the NIK inspectors. Eventually, these plans were put to an end, or at least moved in time, as a consequence of the 2007 parliamentary elections' results.

In connection with the first large coordinated ordered audit in a public finance sector in Poland, which was conducted from June to August 2008, concerning the verification of the process which aims at job positions in the civil service description and evaluation, a successive Minister of Finance regulation was published. ${ }^{13}$ The regulation specifies, among other things, the fact that after the audit tasks are conducted the report or other essential information concerning the audit is handed over. It is a regulation which enables a client to choose a form depending on circumstances and is also an answer to the opposing opinions of the auditing circle which is afraid of its job's verification while handing over such reports. What is more, future rights of the workers of the institutions ordering audits were made viable. That is, in relation to the previous project, the right to freely enter the institutions and premises which undergo an audit process was made invalid while the right to receive the documents in electronic versions was limited to the documents which already exist in such a version. This regulation is the newest source of changes applying to an internal audit in the Polish finance sector units as of the end of the first half of 2008.

\section{The prospects of an internal audit's development}

As far as the regulation prospects concerning an internal audit as well as its practical application are concerned, an undeniable fact is the institution's continuous development in the reality of modern administration creation which is based on the Western European patterns. Monitoring the so called public sector in Poland it must 
be stated that this institution worked in practice. In relation to the above mentioned internal control (in some of the public institutions these units work parallel) an audit is a more modern institution having unified legal frames independent of the manager's will and, first of all, not only pointing out to the existing transgressions and irregularities, but also obliged to prevent them in the future. ${ }^{14}$ In the future years the auditors are faced with serious tasks whose completion is connected with our country's membership in the European Union (both in the scope of the received and expended public means verification as well as the cooperation with the institutions' equivalents in other European countries). An internal audit' approval will be connected with the development of the legal regulation. Observing recent years one can notice a systematic development in regulations or the introduction of new rules and exceptions. It can be assumed that with time the issues connected with an internal audit will be set apart from a regulation concerning public finance. An internal audit will undergo fast legislative diversity depending on the specificity of the researched areas (a national and self-government audit, a centralized audit or a coordinative one ${ }^{15}$ and finally a sector division: a judiciary, finance or education audits). Undoubtedly, the associations and organizations such as: Internal Auditors Association IIA Poland or Public Finance Sector Units Internal Auditors Association may play an important role in the process. The rules of obtaining professional qualifications, which are only temporal now, will depend on their activity and inventiveness. Depending on the conclusions drawn on the basis of conducting a coordinated ordered audit, a decision concerning this institution will be made. In a wider perspective the regulations may lead to the unification of the documents' patterns (based on the model of NIK regulation) as well as the development of procedural regulations (which leads to strengthening contradictory rule's functioning).

What is also worth mentioning is the postulate which suggests introduction of sanctions for not implementing an internal audit despite an existing duty. ${ }^{16}$ This solution will neutralize nonchalant attitude expressed by some of the units' managers towards this institution.

All of the suggested changes will greatly depend on the financial means allocated for them. Such financial means should not only be sufficient for paying appropriate salaries and maintaining the infrastructure but also providing a suitable level of obtaining professional qualifications and giving a possibility to use specialist expert service. Without providing financial means none of the legal regulations, even if they are the best, will enable to conduct auditing tasks in a serious way.

R. Elm - Larsen, Kontrola wykonawcza zadań, Warsaw 2005, p. 15

R. Żukowski, A. Purgot, Audyt wewnętrzny w jednostce samorządu terytorialnego, Warsaw 2005

The interpellation made on 4th December 2006 by W. Dzikowski MP which concerned the postulate made by Higher Education Institution Internal Audit Association (www. Interpelacje.co-myslisz.pl_5780.html). 


\section{Streszczenie}

Wprowadzenie audytu wewnętrznego było związane w dostosowaniem polskiego systemu prawnego do standardów europejskich w wyniku akcesji do UE. Instytucja ta zaczęła funkcjonować $\mathrm{z}$ dniem 1 stycznia $2002 \mathrm{r}$. w wyniku nowelizacji ustawy o finansach publicznych z 1998 r. poprzez dodanie rozdziału 5 zatytułowanego „Kontrola finansowa i audyt wewnętrzny w jednostkach sektora finansów publicznych". Znalazła się ona również w obecnie obowiązującej ustawie o finansach publicznych z 30 czerwca 2005 r., przy czym dokonano w niej wielu znaczących zmian.

Autor artykułu dokonuje porównania głównych elementów audytu wewnętrznego w obu wspomnianych aktach, m.in. zakres przedmiotowy, kwalifikacje audytorów uprawnionych do jego przeprowadzania. 